\section{Interessant om psykometri}

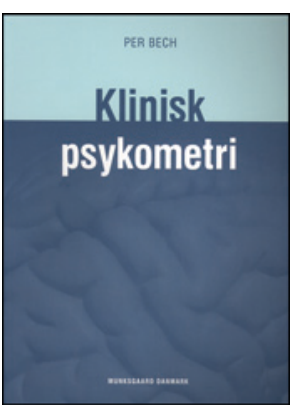

Per Bech

Klinisk psykometri

206 s, tab, ill. København: Munksgaard

Danmark, 2011. Pris DKK 258

ISBN 978-87-628-1011-2

Denne boken er skrevet av nordisk psykometris grand old man, professor Per Bech. Boken «henvender sig til alle, der vil prøve at sette sig ind i, hvorledes den moderne psykiatri er blevet til, og vil gøre sig fortrolig med dens praktiske muligheder. Herunder hvorledes det er muligt at sammenligne forskellige personer med hinanden, hvorledes grænsen mellem det normale og det sygelige kan bestemmes, og hvordan man kan bedømme den kliniske effekt af de forskellige behandlingsmetoder, psykiatrien råder over i dag».

Etter min mening er dette målet mer ambisiøst enn det boken kan leve opp til. Forfatteren gir imidlertid en god oversikt over hvordan moderne psykometri er blitt til. Det er ti kapitler, en ordliste og et fyldig appendiks. I innledningskapitlet gir han en oversikt over psykometriens utvikling og bidragene til en del nøkkelpersoner. Deretter kommer et kapittel om vurdering av diagnosesystemene ICD-10 og DSM-IV, fulgt av fem kapitler om ulike psykometriske vurderinger. Forfatteren legger særlig vekt på vurdering av medikamentell behandling og på vurdering av angst og depresjon. Så kommer to mer oversiktspregete kapitler, Spørgeskemaer som «blodprøver» og Sammenfatning og perspektiv. Det siste kapitlet er igjen en mer historisk oversikt, med tittelen Hvem modtog «Einsteins» stafet?

I ordlisten gir forfatteren en definisjon av en del begreper og kortfattede omtaler av en del sentrale personer, først og fremst danske. I appendikset presenterer han en rekke graderingsskalaer, med hovedvekt på angst og depresjon. Det avsluttes med den kjente forskeren Max Hamiltons Københavnforelesning fra 1977. Den inneholder mye interessant og forstandig.

Boken rundes av med en omfattende referanseliste og et utmerket stikkordregister.

Som nevnt ovenfor sikter denne boken bredt, kanskje litt for bredt. Det er ikke lett å dekke både historikk og konkret, aktuell psykometri på et begrenset antall sider. I noen grad kommer de to målene i konflikt med hverandre. Jeg savner en mer kritisk drøfting av validitetsbegrepet, og også en grundigere behandling av skalaer til bruk ved psykotiske tilstander, og skalaer til bruk for evaluering av psykoterapi og andre psykososiale behandlingsformer. Men boken inneholder mye interessant, og for leger med interesse for psykometri er den vel verd å lese.

\section{Svein Friis}

Avdeling for forskning og utvikling

Klinikk psykisk helse og avhengighet

Oslo universitetssykehus

\section{Livet som flyktningbarn og ung voksen}

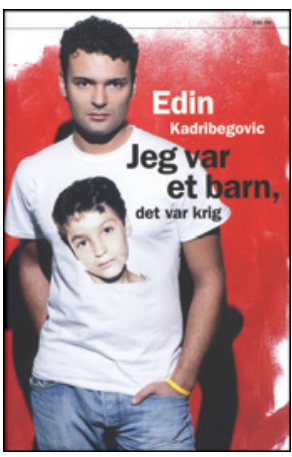

Edin Kadribegovic

Jeg var et barn, det var krig

198 s. Oslo: Pax Forlag, 2012. Pris NOK 299

ISBN 978-82-530-3437-9

Krigen i Bosnia er et sår i Europas sinn og historie - et multikulturelt område som nå står igjen med motsetninger, tap og sorg et land som kjemper for å bygge seg opp igjen, med en befolkning som har krigen med seg hver dag.

Edin Kadribegovic gir på en medrivende måte et innblikk i denne historien. Hans grep om fortellingen er en veksling mellom den lille guttens minner og den voksnes fakta og refleksjoner. Det er et modig tilbakeblikk.

Kadribegovic beskriver hvordan han som ti år gammel gutt før krigen brøt ut i 1992, opplevde hvordan stemningen i landet forandret seg og hvordan han og moren måtte forlate faren, broren og landet. Det er tette skildringer av livet i familien og på skolen der de etniske motsetningene bygger seg opp frem til krigsutbruddet. Det uvirkelige ved krigens absurditeter med broren og familiens medlemmer tett på krigshandlinger blir formidlet gjennom barnets øyne. Hans voksne fortellerstemme beskriver hvordan de politiske motsetningene manifesterer seg, flukten, livet som midlertidig flyktning i Kroatia, og forverringen av situasjonen der. Det vilkårlige i flyktningers liv blir tydelig da de flykter til Norge. Mor og sønn kommer til Norge, og Kadribegovic formidler hvordan livet som asylbarn oppleves. Han gir eksempler på hvordan møter med enkeltmennesker i eksil kan ha stor betydning for veien videre i det nye landet. Tilfeldighetene og farene i livet som flyktning i en usikker krigsregion og i eksil blir godt og tett skildret fra et guttesinn.

Denne boken satte meg tilbake til tiden som kommunelege ved flyktninghelsetjenesten i Kristiansand, da vi tok imot bosniske krigsflyktninger som kom til Norge. Vi trodde vi forsto, men jeg har lært at det meste var umulig å fatte, sette seg inn i og forstå. Etter mange år i dette feltet er det klart at jeg stadig vekk ikke vet alt jeg trenger å vite.

Migrasjonshelse er et felt de færreste leger vet nok om, men alle bør ha en viss kjennskap til feltet. Det er alltid nyttig å lese litteratur fra de landene man møter flyktninger fra. Alt kan ikke sies, og en kultur er så mangfoldig at bøker som denne gir verdifulle tilskudd til innsikt, forståelse - og inspirasjon.

\section{Birgit Lie}

Poliklinikk for psykosomatikk og traumer

Sørlandet sykehus

Kristiansand 